\title{
Chemical Compositions of the Calcium Monosulfate Hydrates Formed by the Hydration of Aluminate Haüyne
}

\author{
Ko IKEDA, Yoshinori NAKAMURA and Hiromi SHIMA \\ Department of Advanced Materials Science and Engineering, Yamaguchi University, 2557, Tokiwadai, Ube-shi

\author{
アルミネートアウインの水和により生成するカルシウムモノサルフェート水和物の化学組成 \\ 池田 攻・中邑義則・島 敞史 \\ 山口大学工学部機能材料工学科, 755 山口県宇部市常盤台 2557
}

\begin{abstract}
Calcium monosulfate hydrates, $\mathrm{Ca}_{4}\left[\mathrm{Al}_{2}(\mathrm{OH})_{12}\right]\left[(1-x) \mathrm{SO}_{4} \cdot x(\mathrm{OH})_{2}\right] \cdot 6 \mathrm{H}_{2} \mathrm{O}$ were synthesized at $20^{\circ} \mathrm{C}$ from aluminate haüyne, $\mathrm{Ca}_{8} \mathrm{Al}_{12} \mathrm{O}_{24}\left(\mathrm{SO}_{4}\right)_{2}$ by hydration under the presence of gypsum and portlandite. The experimental water/solid ratio was 0.80 . Quantitative analysis by EPMA revealed that the $x$ reaches up to 0.16 under the present synthetic conditions where ettringites are considered to be stable at lower water/solid ratios. Stabilities of accompanied phases were discussed in terms of phase assemblage.
\end{abstract}

[Received May 24, 1996; Accepted September 19, 1996]

Key-words : Haüyne, Monosulfate, Cement, Gypsum, Portlandite

\section{Introduction}

Ca-monosulfate hydrates are hydration products in many cement systems such as Portland cements, regulated set cements and Ca-sulfoaluminate cements. The end-member is expressed as $\mathrm{Ca}_{4}\left[\mathrm{Al}_{2}(\mathrm{OH})_{12}\right]\left(\mathrm{SO}_{4}\right) \cdot n \mathrm{H}_{2} \mathrm{O}$ and forms solid solutions with another end-member, $\mathrm{Ca}_{4}\left[\mathrm{Al}_{2}(\mathrm{OH})_{12}\right]$ $(\mathrm{OH})_{2} \cdot n \mathrm{H}_{2} \mathrm{O}$. ${ }^{1)}$ The $n$ is believed to be 6 for both compounds at normal conditions but is variable with humidity. Pöllmann ${ }^{2}$ investigated this solid solution series and found a decreasing incorporation of $\mathrm{Ca}_{4}\left[\mathrm{Al}_{2}(\mathrm{OH})_{12}\right](\mathrm{OH})_{2}$. $n \mathrm{H}_{2} \mathrm{O}$-component with temperatures of formation, i.e., 50 , 33,17 and $0 \mathrm{~mol} \%$ incorporations at $25,45,60$ and $80^{\circ} \mathrm{C}$, respectively. Since the hexagonal lattice constants are quite sensitive to humidity, a great deal of care is required for the determination of the lattice constants. Regulation of humidity is inevitable for X-ray measurements. Accordingly, chemical compositions cannot be determined from the lattice constants by general procedures. In this paper, direct determination of chemical compositions for Ca-monosulfate hydrates will be attempted by employing a microprobe apparatus.

\section{Experimental}

Aluminate haüyne was synthesized from reagent grade chemicals, $\mathrm{CaCO}_{3}, \alpha-\mathrm{Al}_{2} \mathrm{O}_{3}$ and $\mathrm{CaSO}_{4} \cdot 2 \mathrm{H}_{2} \mathrm{O}$ mixed in stoichiometric proportions. A $10 \mathrm{~g}$ batch was burnt at $1200^{\circ} \mathrm{C}$ for $3 \mathrm{~h}$, employing an electric resistance furnace and a platinum crucible. The charge was crushed with grinding in an agate mortar to refire for more than $3 \mathrm{~h}$ at the same temperature to ensure the completion of sintering. Finally, $300 \mathrm{~g}$ sample was obtained by repeating this procedure. The sample was identified by XRD and regulated into fine powder having $2500 \mathrm{~cm}^{2} / \mathrm{g}$ specific surface area by the Blaine method. Then, supposing formations of ettringites, gypsum and portlandite were mixed as following schemes:

$\mathrm{Mix}(1) \mathrm{Ca}_{8} \mathrm{Al}_{12} \mathrm{O}_{24}\left(\mathrm{SO}_{4}\right)_{2}+16\left[\mathrm{CaSO}_{4} \cdot 2 \mathrm{H}_{2} \mathrm{O}\right]$ $+12 \mathrm{Ca}(\mathrm{OH})_{2}+148 \mathrm{H}_{2} \mathrm{O}$ $\rightarrow 6\left\{\mathrm{Ca}_{6} \mathrm{Al}_{2}(\mathrm{OH})_{12}\left(\mathrm{SO}_{4}\right)_{3} \cdot 26 \mathrm{H}_{2} \mathrm{O}\right\} \mathrm{ss}$

Mix (2) $2\left[\mathrm{Ca}_{8} \mathrm{Al}_{12} \mathrm{O}_{24}\left(\mathrm{SO}_{4}\right)_{2}\right]+23\left[\mathrm{CaSO}_{4} \cdot 2 \mathrm{H}_{2} \mathrm{O}\right]$ $+33\left[\mathrm{Ca}(\mathrm{OH})_{2}\right]+314 \mathrm{H}_{2} \mathrm{O}$ $\rightarrow\left\{9\left[\mathrm{Ca}_{6} \mathrm{Al}_{2}(\mathrm{OH})_{12}\left(\mathrm{SO}_{4}\right)_{3} \cdot 26 \mathrm{H}_{2} \mathrm{O}\right]\right.$ $\left.-3\left[\mathrm{Ca}_{6} \mathrm{Al}_{2}(\mathrm{OH})_{12}\left((\mathrm{OH})_{2}\right)_{3} \cdot 26 \mathrm{H}_{2} \mathrm{O}\right]\right\}_{\mathrm{ss}}$

Mix (3) $3\left[\mathrm{Ca}_{8} \mathrm{Al}_{12} \mathrm{O}_{24}\left(\mathrm{SO}_{4}\right)_{2}\right]+176 \mathrm{H}_{2} \mathrm{O}$ $\rightarrow 2\left\{\left[\mathrm{Ca}_{6} \mathrm{Al}_{2}(\mathrm{OH})_{12}\left(\mathrm{SO}_{4}\right)_{3} \cdot 26 \mathrm{H}_{2} \mathrm{O}\right]\right.$

$$
\left.-\left[\mathrm{Ca}_{6} \mathrm{Al}_{2}(\mathrm{OH})_{12}\left((\mathrm{OH})_{2}\right)_{3} \cdot 26 \mathrm{H}_{2} \mathrm{O}\right]\right\} \mathrm{ss}
$$$$
+28\left[\mathrm{Al}(\mathrm{OH})_{3}\right]
$$

where ss denotes solid solutions. For the gypsum and the portlandite, specific surface areas measured were 2000 and $4500 \mathrm{~cm}^{2} / \mathrm{g}$, respectively. Pastes were prepared at 0.80 water/solid (W/S) ratio and cast into molds of $1 \times 1 \times 4 \mathrm{~cm}$ dimension to perform the conventional humid-air curing at $20^{\circ} \mathrm{C}$ for $1 \mathrm{~d}$. After eliminating the surface thin film precipitated from the bleeding water, demolding was done and then the samples were cured in water at $20^{\circ} \mathrm{C}$. Identification of hydrates were carried out by the XRD technique for samples stored in acetone at 1, 3, 7, 28 and $91 \mathrm{~d}$ ages to interrupt hydrations. Quantitative analysis was performed on the $\mathrm{Ca}$ monosulfate hydrates extensively formed, employing JEOL 8600MX microprobe analyzer in the following conditions: $15 \mathrm{kV}$ accelerating voltage, $0.01 \mu \mathrm{A}$ probe current, $5 \mu \mathrm{m}$ probe spot, and TAP and PET analyzing crystals. The ZAF correction was applied, using the above-mentioned aluminate haüyne as a standard material in order to obtain initial values of calculation.

\section{Results and discussion}

\subsection{Hydrates}

Enhanced formation of Ca-monosulfate hydrates were encountered instead of ettringites probably due to the somewhat higher W/S ratio applied in this study. Ettringites were identified nil or slight throughout entire range of curing time in all hardened bodies. It was noted that tetracalcium aluminate hydrates, $\mathrm{Ca}_{4}\left[\mathrm{Al}_{2}(\mathrm{OH})_{12}\right](\mathrm{OH})_{2} \cdot 6 \mathrm{H}_{2} \mathrm{O}$ (so-called 13-hydrates) probably decomposed from $\mathrm{Ca}_{4}\left[\mathrm{Al}_{2}(\mathrm{OH})_{12}\right](\mathrm{OH})_{2} \cdot 12 \mathrm{H}_{2} \mathrm{O}$ (so-called 19-hydrates) due to subsequent dehydration in air were associated slightly as an accessory phase in cases of mixes (1) and (2). Slight vaterite was also identified probably due to partial carbonation of the portlandite added in cases of the same mixes. No appreciable formation of calcite was detected. The starting aluminate haüyne was hydrated almost entirely, especially in cases of mixes (1) and (2) even from the early stage of hydration. No trace of added gypsum was seen from the beginning of curing and was found to be quite reactive, while portlandite remained more or less in entire period of hydration except in mix (3) where no portlandite was introduced as well as gypsum in the starting mix. The general trends of formation of these hydrate minerals are shown in Table 1. 


\subsection{Monosulfate solid solutions}

Crystals of Ca-monosulfate hydrates appeared in thin hexagonal platelets up to $15 \mu \mathrm{m}$ in size as so far postulated by many authors (Fig. 1). Euhedral crystals orienting the hexagonal faces were selected as target crystals and measured values indicating nearly $4: 2$ atomic ratio in respect to $\mathrm{Ca}$ : Al were picked up from a number of trials as correct data. Then, the data were recalculated into $4.00 \mathrm{Ca}$ atoms in number to obtain final data. Results are listed in Table 2 with substitution parameter $x$ between sulphates and hydroxyls defined by the following formula:

$$
\mathrm{Ca}_{4}\left[\mathrm{Al}_{2}(\mathrm{OH})_{12}\right]\left[(1-x) \mathrm{SO}_{4} \cdot x(\mathrm{OH})_{2}\right] \cdot 6 \mathrm{H}_{2} \mathrm{O}
$$

It is quite interesting that monosulfates from mix (2) gives rise to $x=0.03$, being nearly the end-member compositions, while those from mix (1) gives rise to $x=0.16$, the maximum value in this study. Mix (3) gives rise to an intermediate value. Although quite satisfactory data were obtained for the monosulfates from mixes (2) and (3), rather unsatisfactory data were obtained for the monosulfates

Table 1. XRD Results of Hydrates in Correlation with Starting Minerals Summarized for 91d Specimens

\begin{tabular}{|c|c|c|c|}
\hline Mix & (1) & (2) & (3) \\
\hline Haüyne & - & - & * \\
\hline Gypsum & - & - & \\
\hline Portlandite & $* *$ & $*$ & \\
\hline Ettringite & - & $*$ & - \\
\hline Monosulfate & $* * * *$ & $* * * *$ & $* * * *$ \\
\hline 13-hydratef & $*$ & $* *$ & - \\
\hline Vaterite & $*$ & $*$ & - \\
\hline \multicolumn{4}{|c|}{$\begin{array}{l}\text { Presence; - nil, * slight, ** small, *** } \\
\text { medium, **** enhanced. Monosulfate=Calcium } \\
\text { monosulfate hydrate, }\{13 \text {-hydrate }=\text { Tetracalcium- } \\
\text { aluminate hydrate, } \mathrm{Ca}_{4}\left[\mathrm{Al}_{2}(\mathrm{OH})_{12}\right](\mathrm{OH})_{2} \cdot 6 \mathrm{H}_{2} \mathrm{O} \\
\text { However, tetracalcium hemicarbonate hydrate, } \\
\mathrm{Ca}_{4}\left[\mathrm{Al}_{2}(\mathrm{OH})_{12}\right]\left[1 / 2 \mathrm{CO}_{3} \cdot 1 / 2(\mathrm{OH})_{2}\right] \cdot 5.5 \mathrm{H}_{2} \mathrm{O} \text { is } \\
\text { suspected to occur instead, see the text. }\end{array}$} \\
\hline
\end{tabular}

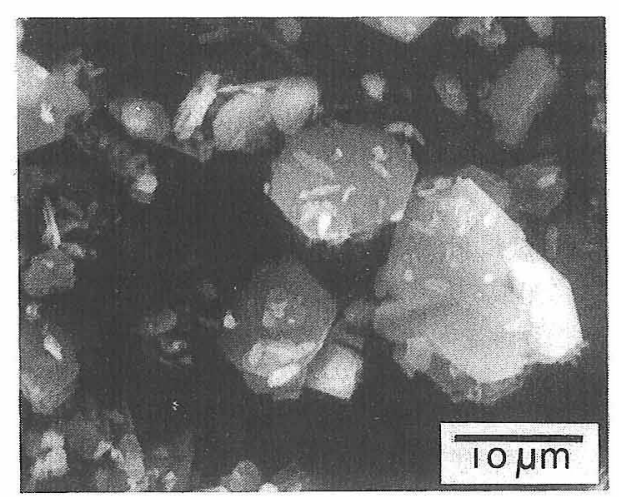

Fig. 1. A typical example of secondary electron image for Camonosulfate hydrates.

Table 2. Results of EPMA Analysis for Ca-Monosulfate Hydrates

\begin{tabular}{|c|c|c|c|c|c|c|c|c|c|}
\hline \multirow{2}{*}{ Key } & \multirow{2}{*}{ Mix } & \multirow{2}{*}{$\begin{array}{l}\text { Age } \\
\text { (d) }\end{array}$} & \multicolumn{3}{|c|}{ Atomic ratio, obs. } & \multicolumn{3}{|c|}{ Atomic ratio, recalc. } & \multirow{2}{*}{$\begin{array}{c}\text { Substitution } \\
x\end{array}$} \\
\hline & & & $\mathrm{Ca}$ & AI & s & $\mathrm{Ca}$ & Al & S & \\
\hline A. & (2) & 7 & 4.05 & 1.99 & 0.98 & 4.00 & 1.96 & 0.97 & 0.03 \\
\hline B. & (2) & 28 & 4.03 & 2.02 & 0.97 & 4.00 & 2.00 & 0.97 & 0.03 \\
\hline c. & (3) & 91 & 4.03 & 2.07 & 0.95 & 4.00 & 2.05 & 0.94 & 0.06 \\
\hline D. & (1) & 28 & 4. 15 & 2.14 & 0.87 & 4.00 & 2.06 & 0.84 & 0.16 \\
\hline
\end{tabular}

from mix (1) probably due to some contaminations from very tiny crystals occurring on the surface of objective crystals. ${ }^{3)}$

According to Pöllmann ${ }^{2)}$ crystals of $\mathrm{Ca}_{4}\left[\mathrm{Al}_{2}(\mathrm{OH})_{12}\right]$ $(\mathrm{OH})_{2} \cdot 12 \mathrm{H}_{2} \mathrm{O}$ which decomposes into $\mathrm{Ca}_{4}\left[\mathrm{Al}_{2}(\mathrm{OH})_{12}\right]$ $(\mathrm{OH})_{2} \cdot 6 \mathrm{H}_{2} \mathrm{O}$ after subsequent drying should coexist with monosulfate solid solutions having $x=0.5$ at $25^{\circ} \mathrm{C}$. Therefore, there may be some contradictions between the literature and present study showing $x=0.16$. There may be some possibilities to explain this occurrence. First, the slight formation of the $\mathrm{Ca}_{4}\left[\mathrm{Al}_{2}(\mathrm{OH})_{12}\right](\mathrm{OH})_{2} \cdot 6 \mathrm{H}_{2} \mathrm{O}$ is metastable in comparison with the results of mix (3). Second, difference of synthetic conditions, i.e., open air for present study and air-tight for the literature ${ }^{2)}$ may be another cause. Although incorporation of carbon dioxide into $\mathrm{Ca}_{4}\left[\mathrm{Al}_{2}(\mathrm{OH})_{12}\right](\mathrm{OH})_{2} \cdot n \mathrm{H}_{2} \mathrm{O}$ crystals is considered to be nil or negligibly small, ${ }^{4), 5)}$ carbon dioxides in air may also give some effects on hydration behavior. ${ }^{8), 9)}$ Third, identification between 13-hydrate, $\mathrm{Ca}_{4}\left[\mathrm{Al}_{2}(\mathrm{OH})_{12}\right](\mathrm{OH})_{2}$. $6 \mathrm{H}_{2} \mathrm{O}$ and quarter carbonate hydrate, $\mathrm{Ca}_{4}\left[\mathrm{Al}_{2}(\mathrm{OH})_{12}\right]$ $\left[1 / 4 \mathrm{CO}_{3} \cdot 3 / 4(\mathrm{OH})_{2}\right] \cdot 5.25 \mathrm{H}_{2} \mathrm{O}$ is difficult due to the similarity of XRD behavior, ${ }^{6)}$ Considering the copresence of vaterite in the 13-hydrate bearing specimens, it is most probable that this 13-hydrate is identical with the quarter carbonate hydrate. However, recent investigations showed no stable formation of the quarter carbonate but hemicarbonate and monocarbonate. 4),7),9) Accordingly, the authors consider that present 13-hydrate should be hemicarbonate or hemicarbonate solid solutions which also show nearly the same XRD patterns with that of the 13-hydrate. Monosulfates including solid solutions are believed to be free from carbonate components and the above estimation is not contradict with the phase assemblage studied by Kuzel and Pöllmann. ${ }^{9)}$ Furthermore, it is quite curious that no starting gypsum was detected during hydration. This should be discussed in view of the formation of vaterite and there may be some possibilities of formation of vaterite from gypsum under aqueous conditions.

\section{Conclusion}

Aluminate haüyne decomposes into Ca-monosulfate hydrates with or without copresence of gypsum and portlandite in aqueous conditions of $0.80 \mathrm{~W} / \mathrm{S}$ ratio, accompanied by some other minor phases as listed in Table 1 . Incorporation of $\mathrm{Ca}_{4}\left[\mathrm{Al}_{2}(\mathrm{OH})_{12}\right](\mathrm{OH})_{2} \cdot 6 \mathrm{H}_{2} \mathrm{O}$-component up to 16 mol\% into $\mathrm{Ca}_{4}\left[\mathrm{Al}_{2}(\mathrm{OH})_{12}\right] \mathrm{SO}_{4} \cdot 6 \mathrm{H}_{2} \mathrm{O}$ was found by EPMA in the experimental conditions investigated and the validity of EPMA measurements was shown for the determination of chemical compositions of monosulfates.

Acknowledgement The authors wish to express their thanks to Japan Cement Association for the financial support.

References

1) H. F. W. Taylor, "The Chemistry of Cements", Vol. 1, Academic Press, London (1964) p. 460.

2) H. Pöllmann, Neues Jahrb. Miner. Abh., 161, 27-40 (1989).

3) K. Sangwal, "Elementary Crystal Growth", Saan Pub., Lublin (1994) p. 556.

4) R. Fischer, H.-J. Kuzel, Cem. Concr, Res., 12, 517-26 (1982).

5) H. F. W. Taylor, "The Chemistry of Cements", Vol. 2, Aca. demic Press, London (1964) p. 442.

6) W. Dosch and H. zur Strassen, Zement-Kalk-Gips, 18, 233-37 (1965).

7) M. H. Roberts, Proc. 5th Inter. Symp. Chem. Cem., Tokyo, 2, 104-17 (1968).

8) H. Pöllmann, 9th Inter. Cong. Chem. Cem., New Delhi, 4, 363-69 (1992).

9) H.-J. Kuzel and H. Pöllmann, Cem. Concr. Res., 21, 885-95 (1991). 